\title{
Analisa Penyebab Kegagalan Kemasan Cup Minuman Instan Aloe Vera
}

\author{
Renty Anugerah Mahaji Puteri*, Meri Prasetyawati \\ Program Studi Teknik Industri, Fakultas Teknik, Universitas Muhammadiyah Jakarta \\ Jl. Cempaka Putih Tengah 27, Jakarta Pusat 10510
}

\begin{abstract}
Abstrak - IKM mempunyai peran penting dan strategis dalam pembangunan ekonomi nasional. Selain berperan dalam pertumbuhan ekonomi dan penyerapan tenaga kerja, juga berperan dalam mendistribusikan hasil-hasil pembangunan. Dalam hal ini adalah IKM yang berlokasi di Kebon Pala Kecamatan Makasar Jakarta Timur yang berbahan baku herbal yang kemudian diolah menjadi makanan dan minuman. Salah satu dari sekian tanaman herbal yang digunakan adalah lidah buaya atau aloe vera. Pada studi pendahuluan yang telah dilaksanakan, diketahui permasalahan yang ditemui pada IKM tersebut diantaranya adalah masih ada dampak dengan adanya kemasan cup minuman instan aloe vera diantaranya penyok, pecah, Maka dibuatlah rancangan solusi yang ditawarkan untuk menyelesaikan masalah tersebut diatas berupa perancangan ulang kemasan cup minuman instan aloe vera. Tujuan dari penelitian ini diantaranya mengidentifikasi atribut apa saja dalam diperlukan dalam menentukan kemasan cup minuman aloe vera dan memberikan usulan dalam menentukan kemasan cup minuman aloe vera. Metode penelitian yang digunakan adalah analisa penyebab dengan Fishbone Diagram dan analisa dengan Failure Methode And Effect Analysis yang terdiri dari identifikasi proses atau produk, analisis kemungkinan setiap potensi mode kegagalan, analisis efek yang ditimbulkan dari terjadinya setiap potensi kegagalan (potential failure mode), menentukan peringkat atau ranking, menghitung nilai Risk Priority Number atau RPN, membuat daftar prioritas perbaikan untuk memperbaiki atau mencegah terjadinya potensi mode kegagalan (potential failure mode), serta membuat analisis usulan perbaikan. Didapat hasil bahwa penyebab kegagalan adalah belum adanya SOP, belum adanya waktu standar melakukan proses pengemasan, ukuran penutup cup dengan meisn kurang sesuai. Tidak adanya pengaturan suhu dan material kemasan kurang sesuai.
\end{abstract}

\section{Pendahuluan}

IKM di Indonesia mempunyai peranan yang penting sebagai penopang perekonomian. Penggerak utama perekonomian di Indonesia selama ini pada dasarnya adalah sektor IKM. Berkaitan dengan hal ini, paling tidak terdapat beberapa fungsi utama IKM dalam menggerakan ekonomi Indonesia, yaitu (1) Sektor IKM sebagai penyedia lapangan kerja bagi jutaan orang yang tidak tertampung di sektor formal, (2) Sektor IKM mempunyai kontribusi terhadap pembentukan Produk Domestik Bruto (PDB), dan (3) Sektor IKM sebagai sumber penghasil devisa negara melalui ekspor berbagai jenis produk yang dihasilkan sektor ini. Dari sekian banyak IKM yang selanjutnya kami sebut sebagai IKM yang berbahan dasar aloe vera dalam pembudidayaan dan pengolahannya adalah sebuah IKM herbal bernama IKM KWT Matahari yang berlokasi di Kebon Pala Kecamatan Makasar Jakarta Timur sebagai pencetus dan penggerak IKM herbal penghasil makanan dan minuman kesehatan seperti minuman aloe vera dalam kemasan dan dalam bentuk bubuk dan keripik aloe vera. Sebelumnya tim Prodi Teknik Industri telah terlebih dahulu melakukan pengabdian masyarakat yang melibatkan IKM KWT Matahari sebagai narasumber pada pelatihan budidaya aloe vera yang diselenggarakan pada April 2017 yang berlokasi di Cileungsi Bogor Jawa Barat.
Hal inilah yang membuka peluang kami dari prodi teknik Industri untuk melakukan pengamatan dan memberikan kontribusi kepada IKM KWT Matahari. IKM ini merupakan satu dari sekian banyak IKM yang berada di Jakarta khususnya di daerah Jakarta Timur yang mempunyai peranan penting dan strategis dalam pembangunan kesejahteraan masyarakat dilingkungan tersebut. Berikut beberapa aktivitas IKM KWT Matahari sehari-harinya yang didominasi ibu-ibu PKK setempat.

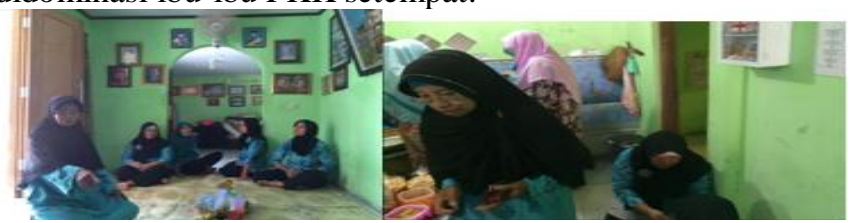

Gambar 1 Kegiatan pada IKM KWT Matahari

Berdasarkan hasil wawancara dan observasi disebutkan bahwa salah satu produk olahannya yakni minuman siap minum aloe vera saat ini hanya dikemas dalam bentuk dan sederhana, sederhana disini belum adanya kriteria pemilihan kemasan cup. Kondisi sederhana ini salah satunya terlihat dari kondisi tempat pembuatan minuman tersebut. Sehingga pada akhirnya dengan kemasan yang menimbulkan dampak seperti mudah pecah, mudah penyok, dsb. Terlihat dari observasi selama 4 bulan terakhir (Juli s/d Oktober 2017) sebanyak $15 \%$ dari total penjualan mengalami pecah. 
Kondisi kemasan sat ini masih tergolong saat sederhana seperti air minum dalam kemasan.

Dari kondisi inilah yang membuat peneliti tertarik untuk memperbaiki dalam hal perancangan ulang kemasan cup minuman aloe vera. Selain itu dengan kondisi kemasan yang ada sekarang masa berlaku penyimpanan pada suhu kamar sangat terbatas, mengingat pangsa pasarnya adalah masyrakat ekonomi bawah yang belum mempunyai lemari pendingin. Tujuan dilakukannya penelitian ini diataranya adalah mengetahui jenis kegagalan produk kemasan cup minuman aloe vera dan memberikan rekomendasi perbaikan kemasan cup minuman aloe vera.

\section{Dasar Teori}

\section{(Cause Effect Diagram atau Fisbone Diagram)}

Diagram ini digunakan untuk menganalisa persoalan dan faktor yang menimbulkan persoalan tersebut. Dengan demikian diagram tersebut dapat digunakan untuk menjelaskan sebab-sebab persoalan. Berkaitan dengan proses secara statistik, diagram sebab akibat dipergunakan untuk menunjukkan faktor-faktor penyebab (sebab) dan karakter kualitas (akibat) yang disebabkan oleh faktor-faktor penyebab itu. (Iskandar, 2008)

Diagram sebab akibat sering juga disebut Ishikawa Diagram karena pertama kali diperkenalkan oleh Prof. Kaoru Ishikawa dari Universitas Tokyo pada tahun 1943 di pabrik Kawasaki Steel Works. Diagram sebab akibat sering juga disebut sebagai diagram tulang ikan (fishbone diagram) karena bentuknya seperti kerangka ikan.

\section{Failure Methode And Effect Analysis ( FMEA )}

FMEA adalah suatu cara di mana suatu bagian atau suatu proses yang mungkin gagal memenuhi suatu spesifikasi, menciptakan cacat atau ketidaksesuaian dan dampaknya pada pelanggan bila mode kegagalan itu tidak dicegah atau dikoreksi. ( Kenneth Crow,2002 )

FMEA biasanya dilakukan selama tahap konseptual dan tahap awal design dari sistem dengan tujuan untuk meyakinkan bahwa semua kemungkinan kegagalan telah dipertimbangkan dan usaha yang tepat untuk mengatasinya telah dibuat untuk meminimasi semua kegagalan kegagalan yang potensial. ( Kevin A. Lange, 2001)

FMEA dapat bervariasi pada level detail dilaporkan, tergantung pada detail yang dibutuhkan dan ketersediaan dari informasi. Sebagaimana pengembangan terus berlanjut, memperkiraan secara kritis ditambahkan dan menjadi Failure, Mode, Effects and Critically Analysis dan $F M E A$. Ada variasi yang sangat banyak didalam industri untuk mengimplementasikan analisis FMEA. Sejumlah standar- standar dan aturan telah dikembangkan untuk menentukan kebutuhan-kebutuhan untuk analisis dan setiap organisasi dapat melakukan pendekatan yang berbeda didalam melakukan analisis.

Pengurutan atau ranking dari berbagai terminologi dalam FMEA adalah sebagai berikut :

1. Akibat potensial adalah akibat yang dirasakan atau dialami oleh pengguna akhir.
2. Mode kegagalan potensial adalah kegagalan atau kecacatan dalam desain yang menyebabkan cacat itu tidak berfungsi sebagaimana mestinya.

3. Penyebab potensial dari kegagalan adalah kelemahan-kelemahan desain dan perubahan dalam variabel yang akan mempengaruhi proses dan menghasilkan kecacatan produk.

4. Occurance $(O)$ adalah suatu perkiraan tentang probabilitas atau peluang bahwa penyebab akan terjadi dan menghasilkan modus kegagalan yang menyebabkan akibat tertentu.

5. Severity $(S)$ adalah suatu perkiraan subyektif atau estimasi tentang bagaimana buruknya penggguna akhir akan merasakan akibat dari kegagalan tersebut.

6. Potential safety problem, akibat yang ditimbulkan adalah sangat berbahaya dan bertentangan dengan hukum

7. Detectibility $(D)$ adalah perkiraan subyektif tentang bagaimana efektifitas dan metode pencegahan atau pendektesian.

8. Risk Priority Number (RPN) merupakan hasil perkalian antara rating severity, detectibility dan rating occurance

$$
\mathbf{R P N}=(\mathbf{S}) \times(D) \times(O)
$$

\section{Risk Priority Numbers in FMEA}

Metodologi Risk Priority Number (RPN) merupakan sebuah teknik untuk menganalisa resiko yang berkaitan dengan masalah-masalah yang potensial yang telah diindentifikasikan selama pembuatan FMEA (Stamatis, DH, 1995, p45)

Sebuah FMEA dapat digunakan untuk mengidentifikasikan cara-cara kegagalan yang potensial untuk sebuah produk atau proses. Metode RPN kemudian memerlukan analisa dari tim untuk mengunakan pengalaman masa lalu dan keputusan engineering untuk memberikan peringkat pada setiap potensial masalah menurut rating skala berikut :

- Severity, merupakan skala yang memeringkatkan severity dari efek-efek yang potensial dari kegagalan.

- Occurance, merupakan skala yang memeringkatkan kemungkinan dari kegagalan akan muncul.

- Detection, merupakan skala yang memeringkatkan kemungkinan dari masalah akan di deteksi sebelum sampai ketangan pengguna akhir atau konsumen.

Setelah pemberian rating dilakukan, nilai RPN dari setiap penyebab kegagalan dihitung dengan rumus :

\section{RPN = Severity $x$ Occurence $x$ Detection}

Nilai RPN dari setiap masalah yang potensial dapat kemudian di gunakan untuk membandingkan penyebabpenyebab yang teridentifikasi selama dilakukan analisis. Pada umumnya RPN jatuh diantara batas yang di tentukan,tindakan perbaikan dapat diusulkan atau di 
lakukan untuk mengurangi resiko. Ketika menggunakan teknik risk assessment, sangat penting untuk mengingat bahwa tingkat RPN adalah relatif terhadap analisis tertentu (dilakukan dengan sebuah set skala peringkat yang umum dan analis tim yang berusaha untuk membuat peringkat yang konsisten untuk semua penyebab masalah yang teridentifikasi selama melakukan analisis). Untuk itu, sebuah RPN didalam sesuatu analisa dapat dibandingkan dengan RPN yang lainnya didalam analisa yang sama, tapi dapat menjadi tidak dapat di bandingkan terhadap RPN didalam satu analisa yang lain.

Meskipun ada banyak tipe dan standar kebanyakan FMEA terdiri dari suatu kumpulan prosedur yang umum. Secara umum, analasis FMEA dipengaruhi oleh tim yang bekerja secara cross function pada tahap yang bervariasi pada waktu desain, proses pengembangan dan perkaitan dan pada umumnya terdiri dari :

- Item/Process : mengidentifikasi item atau proses yang akan menjadi subyek dari analisi.

Termasuk beberapa penyelidikan terhadap desain dan karestirisktik-karakteristik reabilitas.

- Function : mengidentifikasi fungsi-fungsi dimana item atau proses diharapkan untuk bekerja.

- Failures : mengidentifikasi kegagalan yang diketahui dan potensial yang dapat mencegah atau menurunnya kemampuan dari item atau proses untuk bekerja sesuai dengan fungsinya.

- Failure effect : mengidentifikasi efek-efek yang diketahui dan potensial yang mungkin muncul dari setiap kegagalan yang terjadi.

- Failure Cause : mengidentifikasi penyebab yang diketahui dan portensial untuk setiap kegagalan.

- Curent Control : memeriksa mekanisme kontrol yang akan ada untuk mengeliminasi atau menurunkan kemungkinan kegagalan akan muncul.

- Recommended action: mengidentifikasi tindakan perbaikan yang perlu dilakukan yang bertujuan untuk mengeliminasi atau menurunkan resiko dan dilanjutkan dengan melengkapi dengan melakukan recommended action.

- Prioritize issues : memprioritaskan tindakan perbaikan yang harus dilakukan menurut standar yang konsisten yang telah di tentukan oleh perusahaan. Peringkat RPN adalah metode yang umum untuk memprioritaskan

- Other Details : tergantung pada situasi tertentu dan petunjuk untuk melakukan analisa yang di adaptasi oleh perusahaan, keterangan yang lain mungkin dipertimbangkan selama melakukan analisis, seperti cara operational ketika kegagalan muncul.

- Report : membuat laporan dari analisis dalam bentuk format standar yang telah ditentukan oleh perusahaan. Ini pada umumnya berbentuk format tabel. Sebagai tambahan laporan dapat menyertakan diagram berbentuk blok dan atau diagram alir untuk mengilustrasikan item atau proses yang merupakan subject dari analisis.

\section{Metodologi Penelitian}

Lokasi Penelitian

Terdapat dua lokasi penelitian, yakni :

1. Studi lapangan IKM di Kebon Pala Kecamatan Makasar Jakarta Timur DKI Jakarta.

2. Studi laboratorium di Laboratorium Teknik Industri Fakultas Teknik Universitas Muhammadiyah Jakarta Cempaka Putih Tengah 27 Jakarta Pusat.

Studi Pendahuluan

Studi pendahuluan yang telah dilakukan oleh peneliti :

1. Studi lapangan mengenai keberadaan IKM herbal berbahan dasar herbal yang berlokasi di Kebon Pala Kecamatan Makasar Jakarta Timur DKI Jakarta dengan melakukan survey dan observasi di wilayah kecamatan Makasar dan sekitarnya.

2. Perkembangan IKM herbal berbahan dasar herbal saat ini. Untuk mengetahui perkembangan dilakukan studi literature dan mencari informasi secara online.

3. Pola pengelolaan IKM herbal berbahan dasar herbal. Untuk mengetahui perkembangan dilakukan studi literatur dan mencari informasi secara online serta observasi langsung ke IKM herbal sekitar kecamatan Makasar Jakarta Timur

\section{PENGOLAHAN DATA}

1. Analisa Penyebab dengan Fishbone Diagram

2. Analisa dengan Failure Methode And Effect Analysis a. Identifikasi proses atau produk

b.Analisis kemungkinan setiap potensi mode kegagalan c.Analisis efek yang ditimbulkan dari terjadinya setiap potensi kegagalan (potential failure mode)

d.Menentukan peringkat atau ranking dari severity, occurrence, dan detection dengan skala penilaian dari 1 sampai 10

e. Menghitung nilai Risk Priority Number atau RPN

f. Membuat daftar prioritas perbaikan untuk memperbaiki atau

mencegah terjadinya potensi mode kegagalan (potential failure mode)

g. Membuat analisis usulan perbaikanny

\section{Temuan Dan Pembahasan}

\section{Diagram Sebab Akibat}

Dari hasil wawancara dapat disimpukan bahwa reject kemasan minuman cup yakni pecah. Pecah ini disebabkan oleh beberapa sebab. Sehingga pada tahap ini dilakukan pengidentifikasian sumber-sumber penyebab reject pecah dengan menggunakan diagram sebab akibat atau diagram fishbone. 


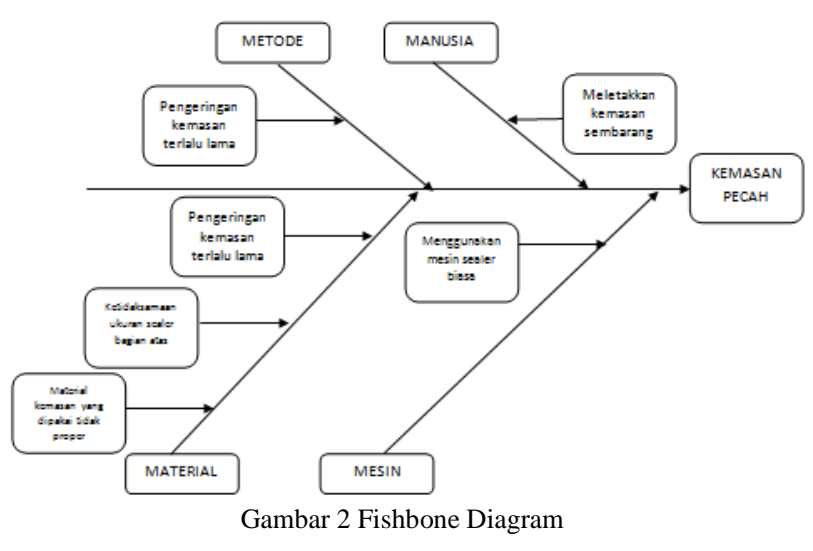

Faktor-faktor penyebab reject yang dituangkan dalam diagram sebab akibat dapat dijelaskan sebagai berikut :

a. Faktor Manusia

Dalm sebuah proses produksi manusia mempunyai andil besar untuk menentukan kualitas produknya. Kurangnya keahlian, ketelitian dan kondisi fisik yang fatigue saat melakukan proses produksi maupun pengemasan dapat menyebabkan kegagalan pada produk kemasan. Kurangnya menjaga keberishan juga dapat mengakibatkan produk cacat.

b. Faktor Mesin

Mesin juga sebagai alat utama dalam sebuah proses produksi juga mempunyai andil dalam keberhasilan sebuah produk. Mesin cup sealer yang digunakan adalah mesin yang biasa digunakan oleh penjaja minuman cappuccino cincau. Sehingga mesin tsb jika digunakan ukurannya kurang sesuai dgn kemasan cup aloe vera. Ukuran cup aloe vera lebih kecil jika dibandingkan dengan mesin cup sealer yang difungsikan. Sehingga menyebabkan kemasan menjadi mudah pecah.

c. Faktor Metode

Ketidakadaannya pengaturan suhu pada mesin cup sealer juga dapatkan mengakibatkan kegagalan pengemasan.

d. Faktor Material

Material yang digunakan dalam mengemas minuman cup adalah jenis HDPE (high density polyethylene). Kekurang sesuaian dapat memberikan dampak yang berbeda pada produk yang dihasilkan dan menimbulkan cacat. Penggunaan mesin sealer yang berulang kali, tidak dilakukan perawatan dan ukuran sealer yang kurang pas/sesuai dapat mengakibatkan kemasan menjadi pecah.

\section{Perhitungan Failure Mode and Effect Analysis}

Agar dapat mengetahui lebih terinci dalam mengidentifikasi penyebab kecacatan produk kemasan, maka dalam penelitian ini dilakukan analisis FMEA yang didapatkan dari hasil analisis diagram sebab akibat. Hasil dari analisis FMEA nantiknya akan diketahui pada bagian mana yang pa,ling menunjukkan hasil perhitungan RPN (Risk priority number) yang dilakukan melalui tahap wawancara serta brainstorming yang melibatkan pemilik IKM dan para pegawai.

Tabel 1. Perhitungan FMEA

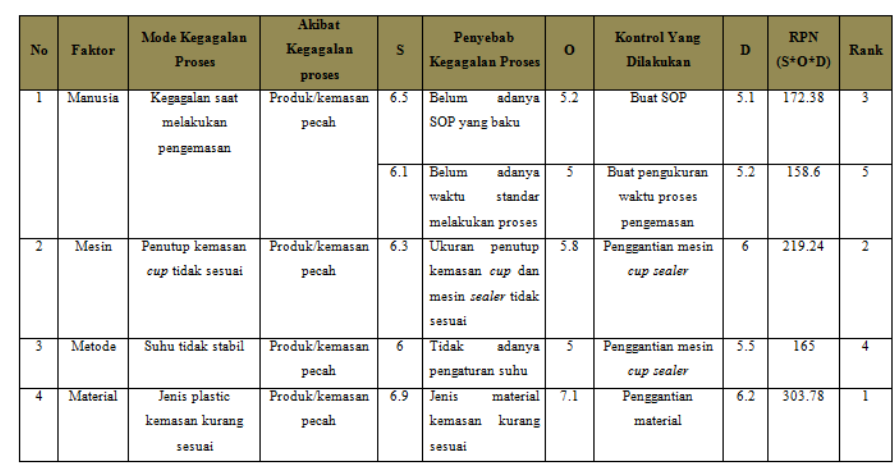

Berdasarkan urutan terbesar maka diperoleh ururtan yang memiliki prioritas nilai RPN yang terbesar yang akan menjadi prioritas perbaikan dalam tahap improvement, yakni :

1. Urutan 1

- Jenis material kemasan kurang sesuai.

- $\quad$ Nilai RPN =

Severity $x$ Occurance $x$ Detection

$=6.9 * 7.1 * 6.2$

$=\mathbf{3 0 3 . 7 8}$

2. Urutan 2

- Ukuran penutup kemasan cup dan mesin sealer tidak sesuai

- $\quad$ Nilai RPN =

Severity $x$ Occurance $x$ Detection

$=6.3 * 5.8 * 6$

$=219.24$

3. Urutan 3

- Belum adanya SOP yang baku

- $\quad$ Nilai RPN =

Severity $x$ Occurance $x$ Detection

$$
=6.5 * 5.2 * 5.1
$$$$
=\mathbf{1 7 2 . 3 8}
$$

4. Urutan 4

- $\quad$ Penggantian mesin cup sealer

- $\quad$ Nilai RPN =

Severity $x$ Occurance $x$ Detection

$=6 * 5 * 5.5$

$=165$

5. Urutan 5

- Buat pengukuran waktu proses pengemasan

- $\quad$ Nilai RPN =

Severity $x$ Occurance $x$ Detection

$=6.1 * 5 * 5.2$

$=158.6$ 


\section{Analisa 5W1H}

Untuk analisis 5W1H didapatkan dari hasil analisis FMEA yang sebelumnya telah kami lakukan. 5W1H merupakan apa (what), mengapa (why), dimana (where), kapan (when), siapa (who) dan bagaimana (how). Metode yang umum digunakan pada tahap perbaikan ini adalah metode penelusuran masalah.

Tabel 2. Analisis 5W1H

\begin{tabular}{|c|c|c|c|c|c|c|}
\hline N & $\begin{array}{l}\text { Apa Peayebabuya } \\
\text { (What) }\end{array}$ & Mengapa (Why) & \begin{tabular}{|c|} 
Dimana \\
Dilakkkan \\
(1Where)
\end{tabular} & Kapan Dilakukan (Then) & $\begin{array}{l}\text { Siapa yang } \\
\text { Melahulan } \\
\text { (Iho) } \\
\text { (Iho) }\end{array}$ & $\begin{array}{c}\text { Bagaimana } \\
\text { Melakukan (How) }\end{array}$ \\
\hline 1 & $\begin{array}{l}\text { Belum addanya SOP } \\
\text { yang balku }\end{array}$ & 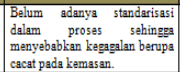 & 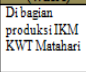 & 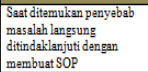 & $\begin{array}{c}\text { Peneliti \& } \\
\text { peleria IITM } \\
\text { KWT Mathari }\end{array}$ & Membuat SOP \\
\hline 2 & \begin{tabular}{|l|} 
Belum adanya \\
waktu tandar \\
melakukun proses
\end{tabular} & 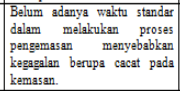 & \begin{tabular}{|l|}
$\begin{array}{l}\text { Dibagien } \\
\text { produlusiKM } \\
\text { KWT Mathasri }\end{array}$ \\
\end{tabular} & 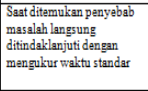 & $\begin{array}{c}\begin{array}{c}\text { Peneliti \& } \\
\text { peleria } \\
\text { KWMT Mathari }\end{array} \\
\text { KWT }\end{array}$ & $\begin{array}{c}\text { Mengulurur waktu } \\
\text { standar }\end{array}$ \\
\hline 3 & \begin{tabular}{|l} 
Ukuran penutup \\
kemasan cup dan \\
mesin icealer tidal \\
sesuai
\end{tabular} & 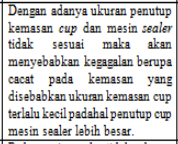 & \begin{tabular}{|l} 
Dibagian \\
pengemasan \\
IKMKWT \\
Matahari \\
\\
\\
\end{tabular} & 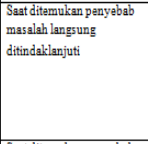 & 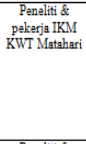 & $\begin{array}{c}\text { Dengen mengeanti } \\
\text { mesin sealer }\end{array}$ \\
\hline 4 & $\begin{array}{l}\text { Tidika adenya } \\
\text { pengagturan suhu }\end{array}$ & 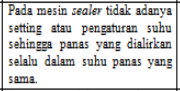 & 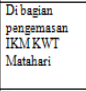 & 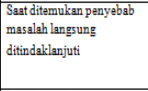 & 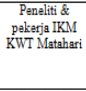 & $\begin{array}{c}\text { Dengen mangeanti } \\
\text { mesin seles }\end{array}$ \\
\hline 5 & \begin{tabular}{|l|}
$\begin{array}{l}\text { Jenis material } \\
\text { kemasan kurang } \\
\text { sesusi }\end{array}$ \\
\end{tabular} & 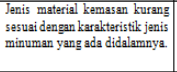 & \begin{tabular}{|l|} 
Di bagian \\
pengemasan \\
IKMKWT \\
Matahari \\
\end{tabular} & 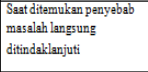 & $\begin{array}{c}\begin{array}{c}\text { Peneliti \& } \\
\text { ppleris } \\
\text { KWM Mathari }\end{array} \\
\text { KWT Mathari }\end{array}$ & $\begin{array}{c}\text { Dengan mengeanti } \\
\text { material }\end{array}$ \\
\hline
\end{tabular}

\section{Simpulan}

Kesimpulan dari penelitian ini adalah :

1. Jenis kegagalan pada produk kemasan cup minuman aloe vera yakni kegagalan saat melakukan pengemasan sehingga penutup kemasan tidak sesuai dan mengakibatkan pecah.

2. Rekomendasi perbaikan kemasan cup minuman aloe vera antara lain :
a. Membuat SOP
b. Mengukur waktu standar sebagai waktu acuan proses pengemasan
c. Mengganti mesin sealer
d. Mengganti material

\section{Kepustakaan}

[1] Rosnani Ginting. Perancangan Produk, Graha Ilmu. 2009.

[2] Indranata ,Iskandar. Pendekatan Kualitatif Untuk Pengendalian Kualitas. Jakarta : Universitas Indonesia Press. 2008

[3] Crow, K. Failure Modes and Effects Analysis (FMEA). DRM Associates. 2002

[4] Kevin, A. Lange, Steven, C.Legget dan Beth, Beker.. Potential Failure and Effect Analysis. AIAG Press. 2001

[5] Hardianto Iridiastadi, Yassierli. Ergonomi Suatu Pengantar. PT Remaja Rosdakarya. 2016

[6] Dr. Ir. Saludin, M.Kom. Desain Untuk Six Sigma. Mitra Wacana Media.2016

[7] Amin Syukron. Pengantar Manajemen Industri. Graha Ilmu. 2014 